\title{
ガラス対金属封止における接着機構
}

\author{
鮫 島 幸 治・西山雅 男 \\ (新日本電気株式会社電子管事業部)
}

\section{Bonding Mechanisms in Glass to Metal Seals}

By

\author{
Yukiharu Sameshima and Masao Nishiyama \\ (New Nippon Electric Co., Ltd., Electron Tube Division)
}

\begin{abstract}
The bonding mechanism of glass to metal seals was investigated on practical sealing materials. On three sorts of glasses (soda-lime glass, boro-silicate glass, and lead glass) to which various metal oxides were added, thermal expansion and contact angle against metals, as well as adherence strength, were measured.

In soda-lime glass to iron metal seals, the introduction of iron oxide into the glass enhanced the corrosion of the metal surface, lowered the contact angle and strengthened the adherence. The change in the thermal expansion, slight as it was, suggested the loosening of network structure or the increase in "effective" chemical bonding. In these seals, physical or mechanical bonding, as well as chemical bonding, seemed to play an important role.

In boro-silicate glass to iron-nickel-cobalt alloy seals, metal oxides introduced into the glass increased the thermal expansion considerably, lowered the contact angle and strengthened the adherence. As compared with the soda-lime glass to iron metal seals, mechanical bonding was rather weak, whereas chemical bonding became stronger. In practical sealing, bonding through oxide interlayer also seemed to participate in the glass to metal adherence.

In glass to chromium seals, the introduction of metal oxides into the glass raised the contact angle, but had no effect on the adherent strength. Oxide interlayer formed by the reaction between molten glass and metal, seemed to play an important role.

In glass to copper seals, adherence by chemical bonding seemed to be effective, but in practical sealing adherence through oxide interlayer seemed also important. [Received Mar. 7, 1966]
\end{abstract}

\section{1. 緒言}

ガラスと金属の接着機構は古くから研究されており， 特に, 珐郎技術に関しては多くの研究結果が報告されて いる・一般に，金属の表面酸化と接着機構は密接な関係 学持っており，酸化物は常に接着機構の主役であると言 っても言い過ぎではなかろう。この接着は，次に述べる よらないくつかの基本的な機構に分類される.

機㳦的結合：ガラスと金属の境界面の川田によって，

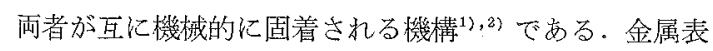
面の凹凸は, 表面酸化の不均一, 粒界の選択酸化拉よび ガラスによる電気化学的侵蝕などによって生成される。 このようにして生じた凹は確かに結合を促進すると信 じられて扮り，金属表面のサンドブラスト処理や薬品に よるエッチングが結合を促進する事実 ${ }^{33}$ がこれ童証明し ている。しかしながら，この機構によってす心゙ての現象 功矛盾なく説明できるわけではない。すなわち，金属の 表面に山界があっても強固な結合が得られずまた逆に 表面が平滑であってもかなり強固な結合が得られる場合
もめる゙ことが知られている。

デンドライトによる結合 ${ }^{5)}$ ：ガラス中に愹解されてい る金属酸化物が電気化学的に還元されて基板上に析出 し，この析出結晶いわゆるデンドライトが，岗たか子金

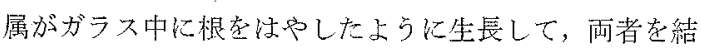
合する機構である。本翼的に流機械的結合の一種と考え られる。この効果を期待して，ガラス中に還元されやす 、金属酸化物，たさえば酸化コバルトなどを添加する瑒 合も少なくない。

化学結合：融着に際して, 基板の表面酸化物がガラス 中に熔解し，これがガラスのネットワーク構造中で修飾 酸化物として働らき，ネットワーク中の酸素架橋を切断 し，その結果ネットワークの強度を低下させる。このよ らにして切断された結合手注，基板側に向きやすくなる から，ガラスと基板の化学的結合を促進寸る ${ }^{6)}$.

逗移層による結合：基板とガラスの間に介在する會属 表面酸化物が，ガラス拉よび金属の严方に結合し，間接 的にガラスと基板が結合される機榡》で多る。たがっ 
て，本質的には化学結合の一種である。

ファンデアワールス結合：2 個以上の原子が化学結合 が生じない程度に近づいた場合に生ずる結合である。結 合力情電的相互作用によって生じ, これ注化学結合の 場合より2 桁程弱(2)。

以上のように，実際問題として，ガラスと金属の接着 には多くの機構が関係している。ところで，珠唧技術の 場合には，種々の材料について接着機構を詳細に研究し た報告は非常に多く，まを䒠験結果の解析を容易にする ために，非実用的な単純な組成のガラスを用いた基礎的 㖄究結果の報告 ${ }^{8)-13)}$ も少なくない。乙かしながら，気 密封止材料汇関する限り，この種の研究結果の報告は非 常に少ない。

本実験は，実用封止材料を使用し，金属酸化物を方 かじ添加したガラスと酸化されていない金属を融着さ せて界面の未熔解酸化物（ガラスとの反忘による酸化物 は別として）の効果を除去し，接触角，接着強度および 界面に扮訬る反応などにおよぼす酸化物の効果を明らか にしこれらの結果から実際の卦止の場合の接着機構の 類推を試みたものである。

\section{2. 試料}

\section{1. 使用材料}

本実験々使用した材料は，表-1 および表-2 に示すと おりのもので，す心゙て実用材料である。

\section{2. 金属酸化物を熔解したガラスの調製}

表一1 に示したガラスを 100 メッシュ以下に粉砕し，

Table 1. Properties of glasses used

\begin{tabular}{|c|c|c|}
\hline $\begin{array}{l}\text { Thermal exp. coeff. } \\
\left(\mathrm{cm} / \mathrm{cm} /{ }^{\circ} \mathrm{C}\right)\end{array}$ & $\begin{array}{l}\text { Soda-lime glass* } \\
99 \times 10^{-7} \\
\left(30^{\circ} \sim 520^{\circ} \mathrm{C}\right)\end{array}$ & $\begin{array}{c}\text { Boro-silicate glass** } \\
\quad 47 \times 10^{-7} \\
\left(30^{\circ} \sim 380^{\circ} \mathrm{C}\right)\end{array}$ \\
\hline Inflection Pt. & 520 & 465 \\
\hline Yielding Pt. & 575 & 540 \\
\hline Density & 2.5 & 2.28 \\
\hline Composition & $\begin{array}{l}\mathrm{SiO}_{2} 71, \mathrm{Na}_{2} \mathrm{O} 17 \\
\mathrm{CaO} 7, \mathrm{Al}_{2} \mathrm{O}_{3} 1.5 \\
\text { rest : } \mathrm{BaO}, \mathrm{MgO}, \mathrm{B}_{2} \mathrm{O}_{3}\end{array}$ & $\begin{array}{l}\mathrm{SiO}_{2} 64.7, \mathrm{~B}_{2} \mathrm{O}_{3} 18.6 \\
\mathrm{Al}_{2} \mathrm{O}_{3} 7.6, \mathrm{BaO} 3.0 \\
\mathrm{~K}_{2} \mathrm{O} 3.4 \\
\text { rest : } \mathrm{Li}_{2} \mathrm{O}, \mathrm{MgO}, \mathrm{CaO}\end{array}$ \\
\hline
\end{tabular}

Nippon Electric Glass Co., Ltd., Code No, SK ${ }^{*}, \mathrm{BH}^{* *}, \mathrm{~L}-29^{* * *}$

Table 2. Properties of metals used

\begin{tabular}{|c|c|c|c|c|c|c|}
\hline $\begin{array}{l}\text { Thermal expo } \\
\left(\mathrm{cm} / \mathrm{cm} /{ }^{\circ} \mathrm{C}\right)\end{array}$ & $\begin{array}{c}\mathrm{Fe}^{(1)} \\
136 \times 10^{-7}\end{array}$ & $\begin{array}{c}\mathrm{Fe} / \mathrm{Ni} / \mathrm{Co}^{(2)} \\
47.5 \times 10^{-7} \\
\left(30^{\circ} \sim 380^{\circ} \mathrm{C}\right)\end{array}$ & $\begin{array}{c}\mathrm{Fe} / \mathrm{Ni}^{(3)} \\
95 \times 10^{-7} \\
\left(30^{\circ} \sim 500^{\circ} \mathrm{C}\right)\end{array}$ & $\begin{array}{c}\mathrm{Fe} / \mathrm{Ni} / \mathrm{Cr}^{(2)} \\
98 \times 10^{-7} \\
\left(30^{\circ} \sim 400^{\circ} \mathrm{C}\right)\end{array}$ & $\begin{array}{c}\mathrm{Fe} / \mathrm{Cr}^{(4)} \\
108 \times 10^{-7} \\
\left(30^{\circ} \sim 500^{\circ} \mathrm{C}\right)\end{array}$ & $\begin{array}{c}\mathrm{Cu}^{(5)} \\
178 \times 10^{-7} \\
\left(25^{\circ} \sim 300^{\circ} \mathrm{C}\right)\end{array}$ \\
\hline$\underset{\left({ }^{\circ} \mathrm{C}\right)}{\text { Inflection }} \mathrm{Pt}$. & - & 435 & - & - & - & - \\
\hline $\begin{array}{c}\text { Composition } \\
(\text { wt } \%)\end{array}$ & $\begin{aligned} \mathrm{Mn} & : 0.053 \\
\mathrm{P} & : 0.08 \\
\mathrm{~S} & : 0.01 \\
\mathrm{C} & : 0.013\end{aligned}$ & $\begin{array}{c}\mathrm{Ni}: 29.0 \\
\mathrm{Co}: 17.2 \\
\mathrm{C}<0.06 \\
\mathrm{Si}<0.2 \\
\mathrm{Mn}<0.5 \\
\mathrm{Fe}: \mathrm{bal}\end{array}$ & $\begin{array}{c}\mathrm{Ni}: 50.5 \\
\mathrm{Mn}<0.8 \\
\mathrm{Si}<0.4 \\
\mathrm{Fe}: \text { ball }\end{array}$ & $\begin{aligned} \mathrm{Ni} & : 42.5 \\
\mathrm{Cr} & : 5.6 \\
\mathrm{Co} & : 0.06 \\
\mathrm{Si} & : 0.19 \\
\mathrm{Mn} & : 0.16 \\
\mathrm{C} & : 0.01 \\
\mathrm{Fe} & : \text { bal }\end{aligned}$ & $\begin{aligned} \mathrm{Cr}: 28 \\
\mathrm{Ni}<0.4 \\
\mathrm{Mn}<1.0 \\
\mathrm{C}<0.2 \\
\mathrm{Fe}: \text { bal }\end{aligned}$ & $\begin{aligned} \mathrm{Si} & <0.05 \\
\mathrm{As} & <0.003 \\
\mathrm{~S} & <0.01 \\
\mathrm{Mn} & <0.4 \\
\mathrm{Fe} & <0.05 \\
\mathrm{Cu} & : \text { bal }\end{aligned}$ \\
\hline
\end{tabular}

(1) Commercial low carbon steel

(2) Sumiromo Special Metal Co., Ltd.

(3) Sumitomo Electric Ind. Co., Ltd.

(4) Nippon Metal Ind. Co., Lid.

(5) Oxygen tree high-conducting copper (OFHC)
これに試薬級の金属酸化物を所定の量だけ添加し, 瑪㷎 乳鉢で充分混合した後, 開放型の電気炉中で, $1000^{\circ} \mathrm{C}$. で 30 分間加熱熔融させた。容器にはグラファイト製の 浅い且学使用し，熔解後ガラスを砕いて，上面中央部加 らカレットを取り出して試料とした。ただし，後に述べ る鉄・ニッケル・コバルト合金と硼珪酸ガラスの系の場 合だけは，合金を空気中 $950^{\circ} \mathrm{C}$ で加熱して表面に生成 された酸化物を採取し，これを上と同様な手順でガラス 中に熔解させた。

これらのガラスを光学顕微鏡および X 線回折で調べ た結果では，いずれも酸化物の添加量が少なくとも20 wt\% までは均一なガラス質になっていることが確認さ れた。またいずれも添加量 $40 \mathrm{wt} \%$ では，顕微鏡的に む X 線的にも末熔解酸化物の存在が認められたので, 本害験の条件では，酸化物の熔解しらる限度は，20４0 wt\% の間に存在していることになる。

\section{3. 金属基板の処理}

クロムとガラスの接着には，銅または鉄・ニッケル。 コバルト合金に厚いクロムメッキを施したものを用い た。これはクロム板の入手が困難なことと，熱膨脹差に よる歪の影響をできるだけ少なくするためにガラスの種 類によって基板を変えたほらがよいと考えたためであ る。他の材料は所定の形状に加工した後トリクレンで洗 浄し，充分焼きなまして使用した。ク口ムをメッキした 材料就よびク口ムを含有する合金の焼きなましは，すい゙ て真空中 $\left(10^{-5} \mathrm{mmHg}\right)$ で約 $1000^{\circ} \mathrm{C}$ で 30 分間扣熱し て行なった．他の材料の焼きなましは，真空中でガラス と融着させる場合には真空中

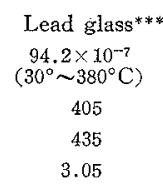

$\mathrm{SiO}_{2} 56, \mathrm{PbO} 30.2$

$\mathrm{K}_{2} \mathrm{O} 6.5, \mathrm{Na}_{2} \mathrm{O} 5$

rest : $\mathrm{Al}_{2} \mathrm{O}_{3}, \mathrm{BaO}$ $\mathrm{B}_{2} \mathrm{O}_{3}$ で，垶素中でガラスと融着させ る場合にはアンモニア分解ガス 中で，いずれも $1000^{\circ} \mathrm{C}$ で 30 分間加熱して行なった. 試料は 寸ぶて完全に椧却されてから空 気中に取り出し，全く酸化され た形跡の見られない状態で実験 に供した。

\section{3. 実験結 果}

\section{1. 金属酸化物熔解量と接} 触角の関係

ガラスと融着させる金属の酸 化物学添加して調製したガラス と金属基板の接触角空測定し， 酸化物の熔解量と接触角の関倸 を各系列の材料の組み合わせに ついて調べた. 融着は, 窒素中 および真空中で行なった。金属 
基板の大きさは $20 \times 30 \mathrm{~mm}$ とした。窒素は, 露点が 一 $45^{\circ} \mathrm{C}$ になるまで乾燥したもの堂使用した。この場 合，加熱法内径約 $50 \mathrm{~cm}$ の石英管をエレマ発熱体で間 接的に加熱する雾囲気電気炉によって行なった，加熱部 の長さ注約 $700 \mathrm{~mm}$ で，この中央の均熱部に同系列の 試料を同時に 4 個聥入した。試料の長さは 1 個あたり $30 \mathrm{~mm}$ であるから，試料挿入部の長さは約 $120 \mathrm{~mm}$ で あり，均熱性は熱電対で確認すると共に，試料の挿入順 序を入れ换えて接触角の変化が霓入順序の影響を受けて いないことを確認した，真空加熱の場合には，内径約 $40 \mathrm{~mm}$ の石英管をニクロム線で間接加熱する方式の炉 を用いた。加熱部の長さ注約 $500 \mathrm{~mm}$ で, 試料の均熱 性については窒素中加熱の場合と同様な方法で確認し た。真空度は $10^{-5} \mathrm{mmHg}$ に保持したが，ガラスの発泡 のために, 瞬閒的に $10^{-4} \mathrm{mmHg}$ のオーダーまで低下す ることも㐫った，图-1 は各系列の試料について得られ た結果である。接触角怜泠却後に投影器を用いて測定 し，直交する 2 方向から測定した 4 点の平均值である。

これらの結果を見ると, クロムと酸化ク口ムを熔解した ガラスの系列以外で注，一定の酸化物熔解量で接触角注 檽小值を示している。

\section{2. 金属酸化物熔解量亡ガラスの熱膨脹率の関係}

試料ガラスをバーナーで加熱し，ピンセットで直径 3〜 $5 \mathrm{~mm}$ の棒状に成形し，両端を平滑に研磨して長さ $50 \mathrm{~mm} \pm 0.1 \mathrm{~mm}$ に仕上げた後, 充分歪を除去したもの
を測定用の試料とした。熱膨脹貫線注オプチカルレバ 一によるディラトメーターで求めたもので，加熱速度は $3^{\circ} \mathrm{C} / \mathrm{min}$ とした。各系列のガラスについて得られた結果 は，図-2 に示すと和りである。

\section{3. 金属酸化物熔解量亡接着強度の関係}

本実験の系列の試料では，接着強度を定量的に求める ことは非常に困難で㐫る。すなわら，ガラス中に酸化物 が熔解されていくと，熱膨脹率が変化するために，す心゙ ての試料について無歪の試験片を作ることは事春上でき ない。そこで，一般的によく使用される簡単な方法であ るが，ガラスを金属基板上に融着させた後，金属板を曲 げてガラスを砕き，その剥離の状態を観察した。この場 合，接着が弱ければガラスは完全に金属基板からはがれ 落ちてしまうが，接着が強ければガラスは変形によって 砕けてもその破片は強固に基板に付着しており，理想的 な場合には金属面訬しも露出しない，中間的な接着強 度の場合には，これらの中間的な状態が見られる。これ らの実驗結果を表-3に, 試験片の外観の一例を図 -3 に 示す。これらによると,クロムと酸化クロムを熔解した ガラスの系列以外では，金属酸化物がガラス中に熔解さ れると，接着強度はこれによって明らかに改善されるこ とがわかる。

\section{4. 顯微鏡䚀察結果}

接着強度を調べた試料について，ガラスが除去された 部分の金属表面を光学顕微鏡で観察した，その結果，ク

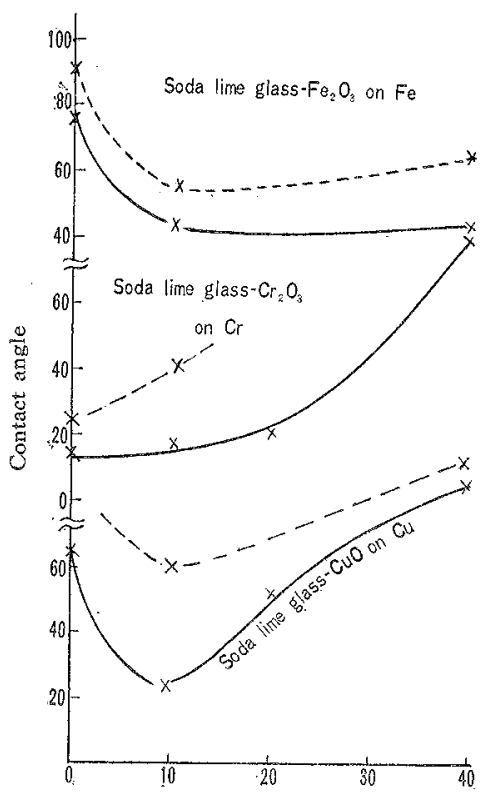

wt $\%$ of oxides added to glass (a)

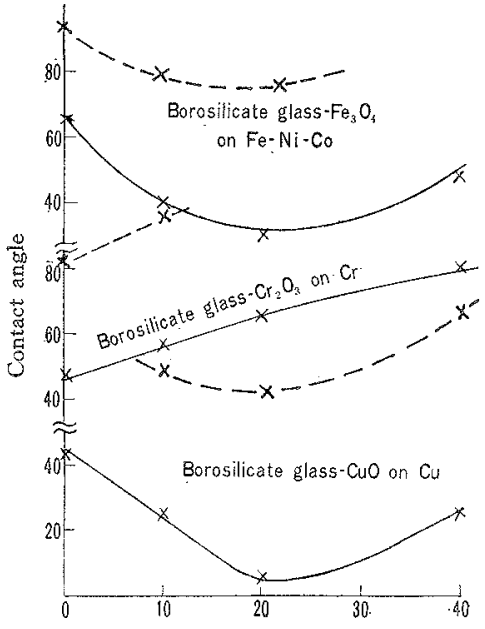

wt $\%$ of oxides added to glass (b)

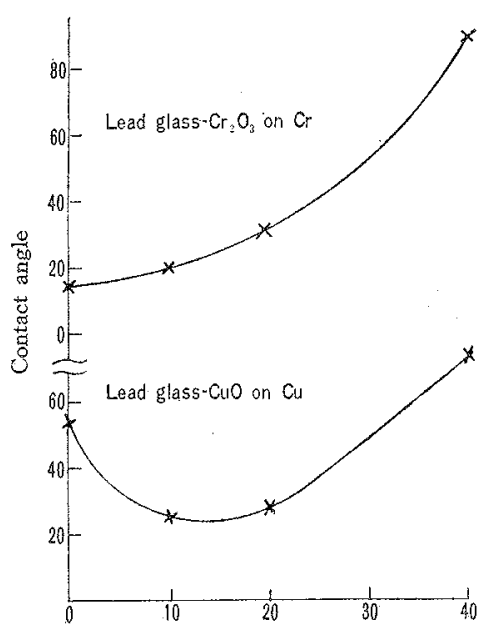

wt $\%$ of oxides added to glass (c)

-- Vacuum, $950^{\circ} \mathrm{C}, 0.5 \mathrm{~h}-\mathrm{N}_{2}, 990^{\circ} \mathrm{C}, 1 \mathrm{~h}$

(a) Soda-lime glass to iron, chromium and copper metals.

(b) Boro-silicate glass to iron-nickel-cobalt alloy.

(c) Lead glass to chromium and copper metals.

Fig. 1. Effect of oxide additions on contact angle. 


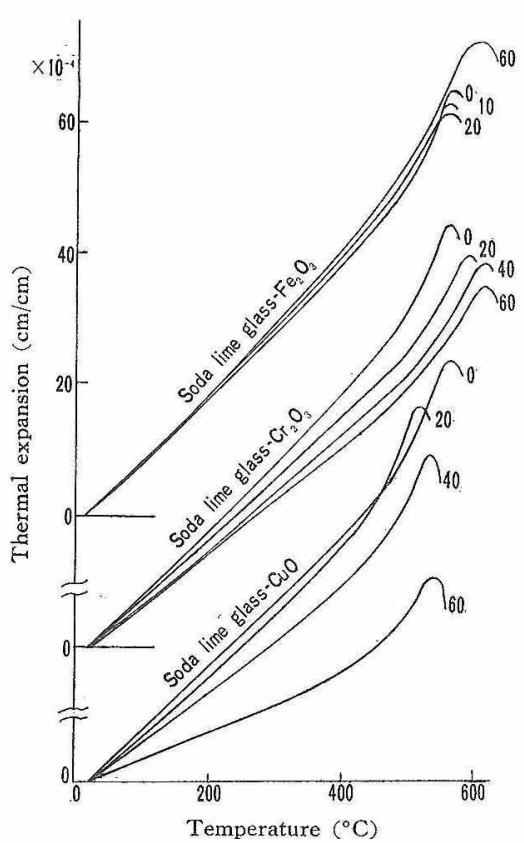

(a)

(a) Soda-lime glass.

(b) Boro-silicate glass.

(c) Lead glass.

$(0,20,40$ and 60 show wt $\%$ of oxide additions.)

Fig. 2. Effect of oxide additions on the thermal expanion of glasses.

Table 3. Result of adherence test

Combination of materials

\begin{tabular}{cl} 
base metal & \multicolumn{1}{c}{ glass } \\
$\mathrm{Fe}$ & soda-lime \\
$\mathrm{Fe} / \mathrm{Ni} / \mathrm{Co}$ & boro-silicate \\
$\mathrm{Cr}$ & soda-lime \\
$\mathrm{Cr}{ }^{* *}$ & boro-silicate \\
$\mathrm{Cr}$ & lead \\
$\mathrm{Cu}$ & boro-silicate \\
$\mathrm{Cu}$ & soda-lime
\end{tabular}

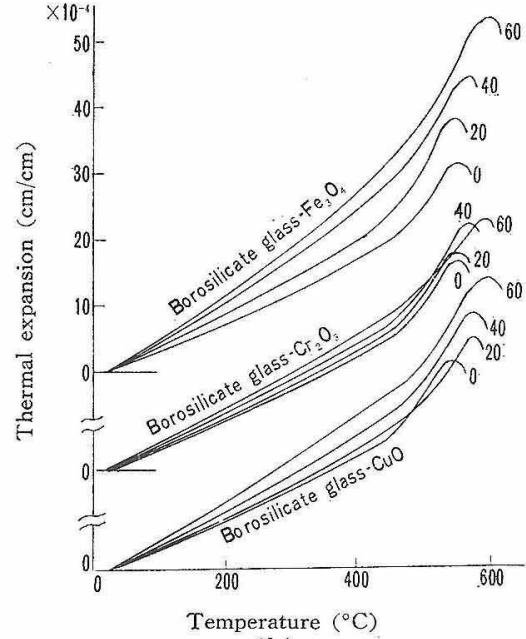

(b)

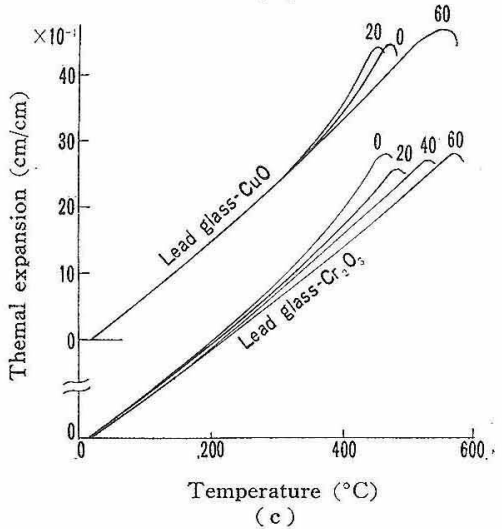

ロムと酸化ク口ムを熔解 したガラスの系列以外で は，基板金属と同じ金属 の酸化物をガラス中に熔 解させておくと，ガラス による金属の侵蝕が促進 されることが明らかにな った. 図-4〜7 はこの状 態を示すむのである. 図 -4 は鉄とソーダライム ガラス, 図 -5 は鉄ニッ ケル・コバルト合金と硼 珪酸ガラスの系列の場合 であるが，いずれも金属 酸化物をガラス中に熔解 させておくことにより， ガラスによる金属の侵蝕 は明らかに促進されてお り，特に金属の結晶粒界 が侵蝕されて組織が明瞭 に現われている.図-6に 示されているクロムと酸 化ク口ムを熔解させたガ ラスの系列では，この効 果は明瞭でない。図-7に 示されている銅と酸化銅 を含有したガラスの系は，図-4および図-5 の場合と傾 向は同じであるが，ガラスに侵蝕された部分は，組織が 明膫に現われると同時に全体が光沢を增している。この ため，ガラスと接触しなかった部分（写真の左側）との コントラストが非常に大きくなっている。

これらの侵蝕状態をさらに詳細に調べるために, 試料 の断面を通常の金属学的手法によって観察した. 図-8 は，酸化銅を熔解したガラスと銅の融着部の断面の組織 走示すものである。図-9(a) は，酸化銅を添加（CuO として 40 wt 6 ) したがラスを粉硴して， ディフラクト

vs : very strong. exposure of metal surface $<1 / 2$

$\mathrm{s}$ : Strong. intemediate of $\mathrm{vs}$ and $\mathrm{w}$

w : weak. Perfect exposure of metal surface $\mathrm{Cr}^{*}$ : Chromium plated copper

$\mathrm{Cr}^{* *}$ : Chromium plated iron-nickel-cobalt alloy

\begin{tabular}{lccc} 
wt $\%$ of oxide in glasses \\
\hline $0 \%$ & $10 \%$ & $20 \%$ & $40 \%$ \\
w & s & vs & w \\
w & s & s & w \\
vs & vs & vs & vs \\
vs & vs & vs & vs \\
s & s & s & s \\
s & vs & vs & vs \\
s & vs & vs & vs
\end{tabular}

vs

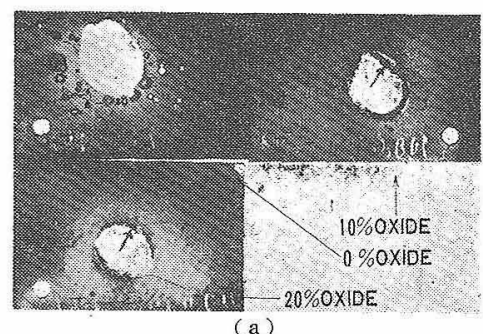

(a)

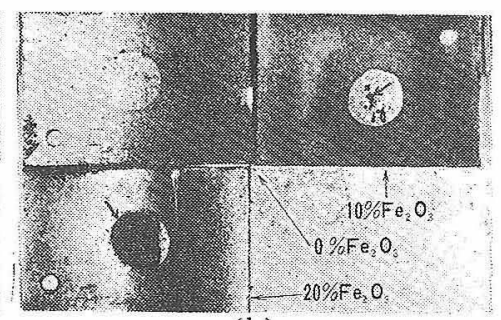

(b)

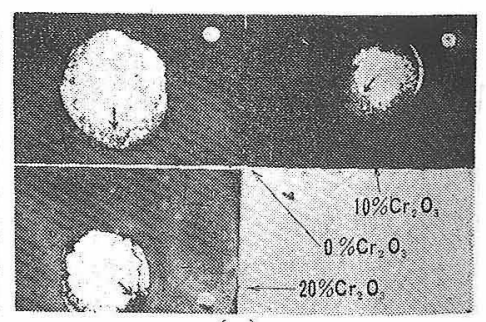

(c)

(a) Iron-nickel-cobalt alloy to boro-silicate glass with oxides of alloy metals (essentially consisting of $\mathrm{Fe}_{3} \mathrm{O}_{4}$ ).

(b) Iron metal to soda-lime glass with $\mathrm{Fe}_{2} \mathrm{O}_{3}$ additions

(c) Chromium metal to lead glass with $\mathrm{Cr}_{2} \mathrm{O}_{3}$ additions (Arrows in the photographs show glass fragments remaining not peeled.)

Fig. 3. Aspect of adherence test specimens. Metal bases were coated by glasses to which various amounts of oxides of the same metals as the bases were added. Specimens were heated at $990^{\circ} \mathrm{C}$ for 30 min. in $\mathrm{N}_{2}$ atmosphere, then bent until the glass coats were cracked. 


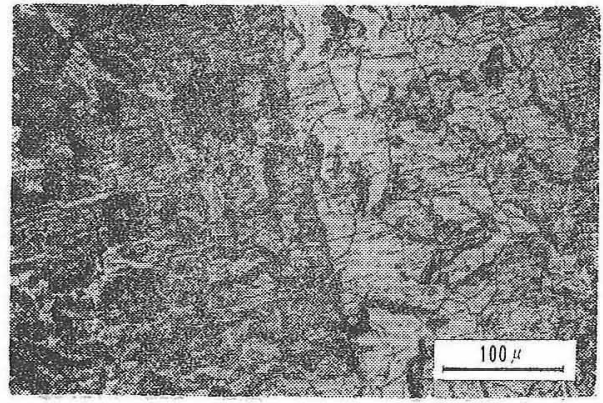

(a)

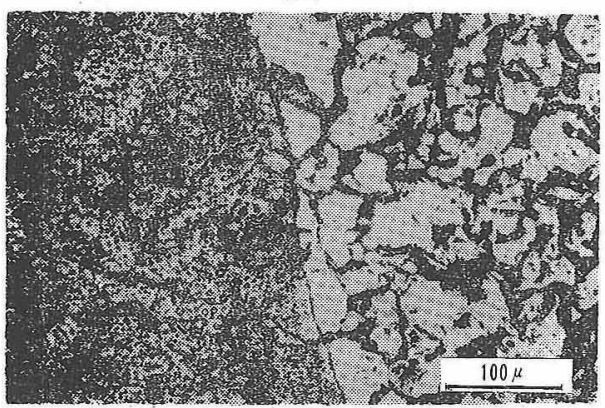

(b)

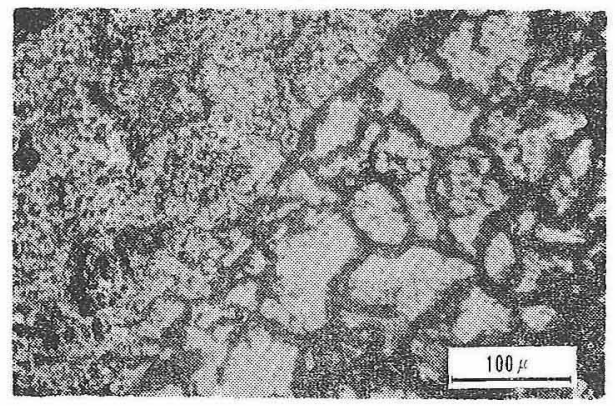

(c)

(a) without additions. (b) with $10 \mathrm{wt} \%$ of $\mathrm{Fe}_{2} \mathrm{O}_{3}$. (c) with $20 \mathrm{wt} \%$ of $\mathrm{Fe}_{2} \mathrm{O}_{3}$.

Note that corrosion was enhanced as the iron content was increased.

Fig. 4. Surfaces of iron metal in contact with soda-lime glass coats with various amounts of $\mathrm{Fe}_{2} \mathrm{O}_{3}$ addi. tions. Specimens were glass-coated by heating at $990^{\circ} \mathrm{C}$ for $30 \mathrm{~min}$. in $\mathrm{N}_{2}$ atmosphere, then the glass separated mechanically. The left sides were not coated for the reference.

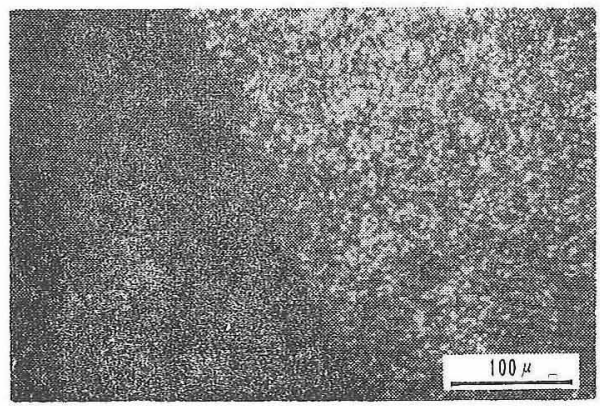

(a)

(a) without additions.

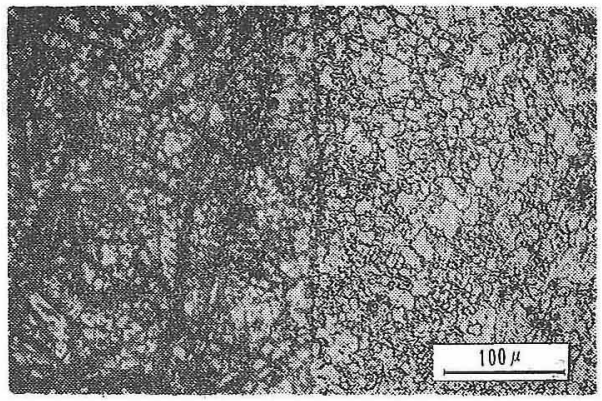

(a)

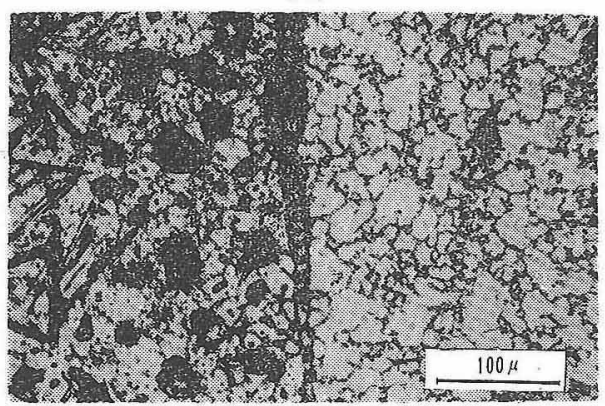

(b)

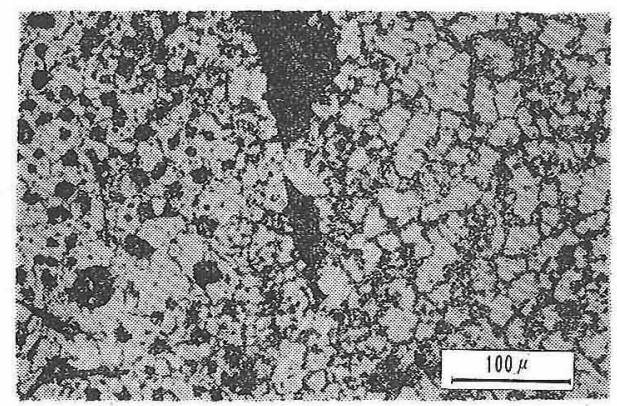

(c)

(a) without additions. (b) with $10 \mathrm{wt} \%$ of oxide adition.

(c) with $20 \mathrm{wt} \%$ of oxide addition.

(Exposure was adjusted to the right side (corroded area).)

Fig. 5. Surfaces of iron-nickel-cobalt alloy in contact with boro-silicate glass coats with various amounts of oxides of alloy metals (essentially consisting of $\mathrm{Fe}_{2} \mathrm{O}_{3}$ ). The experimental method is the same as in Fig. 4.

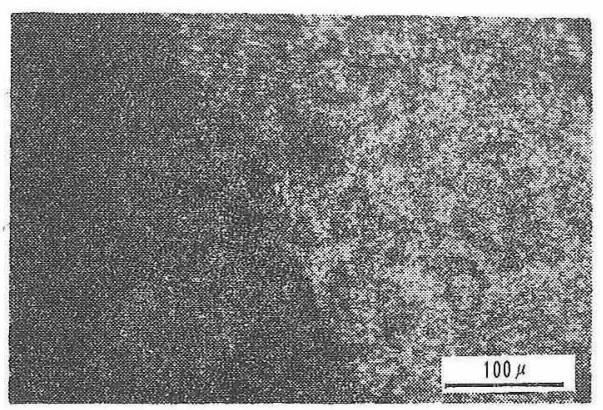

(b)

Fig. 6. Surfaces of chromium metal (electroplated) in contact with boro-silicate glass coats with various amounts of $\mathrm{Cr}_{2} \mathrm{O}_{3}$ additions. The experimental method is the same as in Fig. 4. 


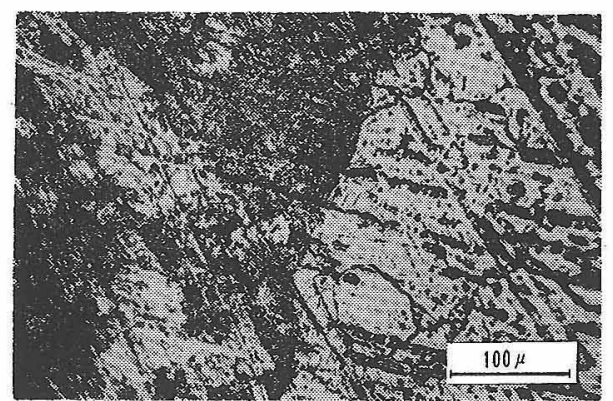

(a)

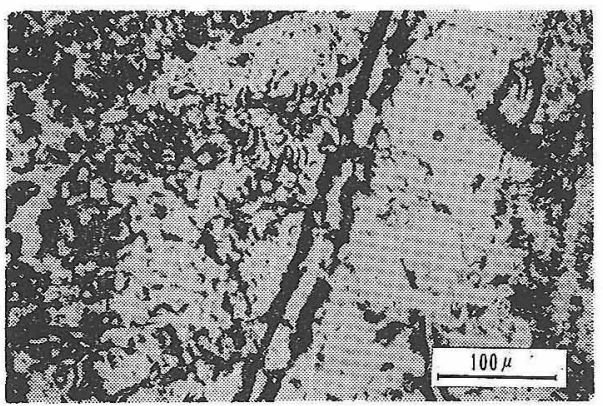

(b)

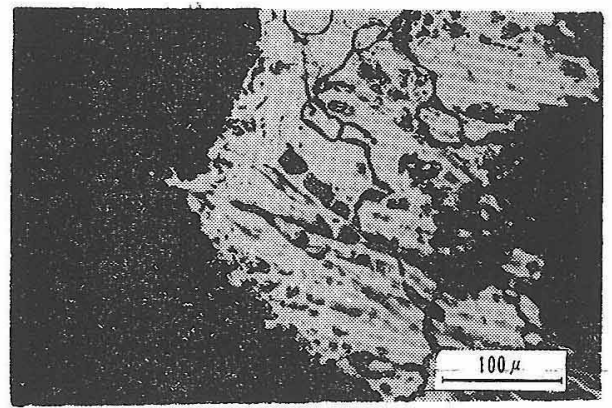

(c)

(a) without additions (b) with $10 \mathrm{wt} \%$ of $\mathrm{CuO}$ (c) with $20 \mathrm{wt} \%$ of $\mathrm{CuO}$

Eig. 7. Surfaces of copper metal in contact with lead glass coats with various amounts of $\mathrm{CuO}$ added. The experimental methodis the same as in Fig. 4.

メーターによって得た X 線回折図である。すなわち図 -8 の融着前のガラスに相当するものである。図-9(b) は，このガラスを銅基板と融着させた後，基板からガラ スを機械的にはがし取り，同様に粉砕して得た X 線回 折図である。すなわち，これは図一-8のガラス部分に相 当するむのである。図-9(a) の指数を記入したピークは $\mathrm{CuO}$ (単斜晶)，図-9(b) のそれは $\mathrm{Cu}_{2} \mathrm{O}$ (正方晶) に 効応している、これらの結果から，未熔解の $\mathrm{CuO}$ は銅 と接触すると酸化還元反応により $\mathrm{Cu}_{2} \mathrm{O}$ に変化するもの と推定される. 写真における $\mathrm{Cu}_{2} \mathrm{O}$ 結晶の発達の状態 と，酸化銅の添加による銅表面の侵蝕の促進効果加ら考 えて，融着部で

$\mathrm{CuO}($ in glass $)+\mathrm{Cu}($ substrate $) \rightarrow$ $\mathrm{Cu}_{2} \mathrm{O}$ (in glass)

で示される反応が起こっていることは確かであるう。

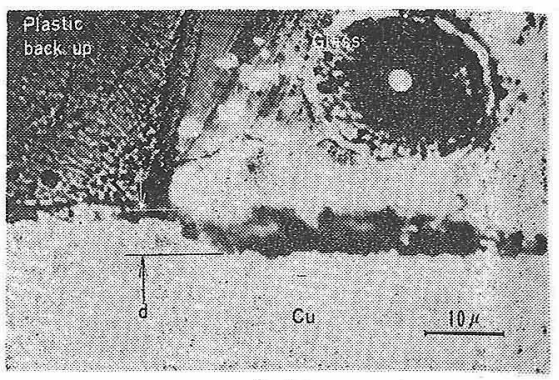

(a)

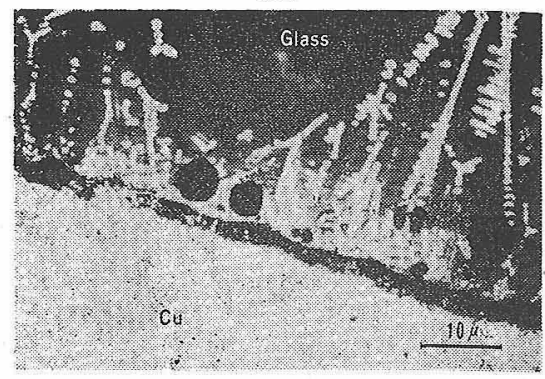

(b)

(a) Copper metal was deeply corroded by the glass. The length " $d$ " shows the corroded depth.

(b) A different area of the same specimen.

Fig. 8. Cross section of interfaces of copper metal and soda-lime glass with $40 \mathrm{wt} \%$ of $\mathrm{CuO}$ added. The specimen was heated at $990^{\circ} \mathrm{C}$ for $30 \mathrm{~min}$. in $\mathrm{N}^{2}$ gas.

(a)
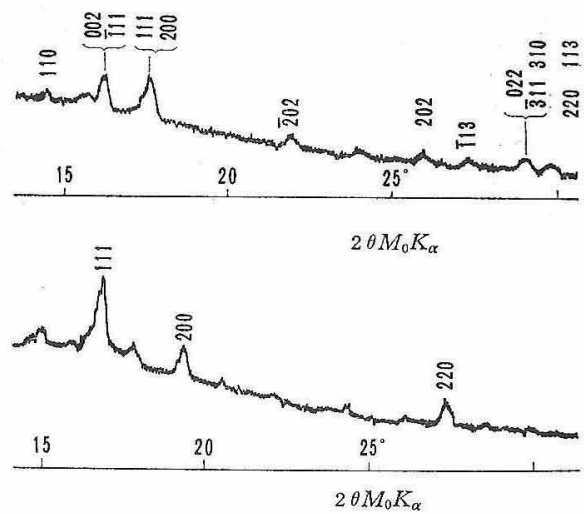

(a) Powdered glass prepared as 2-2. Indexed peaks are identified as $\mathrm{CuO}$ (monoclinic).

(b) Powdered glass separated from copper base shown in Fig. 8. Indexed peaks are identified as $\mathrm{Cu}_{2} \mathrm{O}$ (cubic).

Fig. 9. X-ray powder diffraction diagrams of soda-lime glass with copper addition ( $40 w t \%$ as $\mathrm{CuO}$ ), showing that undissolved $\mathrm{CuO}$ was changed into $\mathrm{Cu}_{2} \mathrm{O}$ by the reaction with copper metal base.

同様にして，酸化ク口ムを添化したガラスとクロムの 反応を X 線的に調心゙た結果を図-10に示す. 図-10(a) は酸化ク口ムを添加 $\left(\mathrm{Cr}_{2} \mathrm{O}_{3}\right.$ として $\left.40 \mathrm{wt} \%\right)$ した鉛ガ ラスを粉砕して得た X 線回折図である。指数を記入し たピ一クは末熔解の $\mathrm{Cr}_{2} \mathrm{O}_{3}$ (六方晶) に﨎応している. 図-10(b) は，このガラスとクロムを窒素中で融着させ た後基板からガラスを機械的にはがし取り，同様に粉砕 
(a)

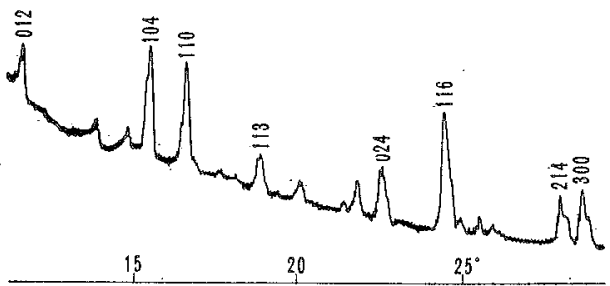

(b)

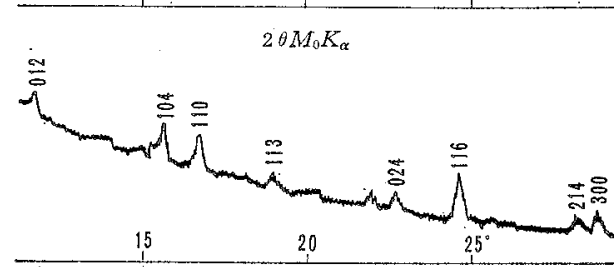

$2 \theta M_{0} K_{\alpha}$

(a) Powdered glass prepared as 2-2. Indexed peaks are identified as $\mathrm{Cr}_{2} \mathrm{O}_{3}$ (hexagonal)

(b) Powdered glass separated from chromium metal base shown in Fig. 6 (b).

Fig. 10. X-ray powder diffraction diagrams of lead glass with chromium addition ( $40 \mathrm{wt} \%$ as $\mathrm{Cr}_{2} \mathrm{O}_{3}$ ), showing that undissolved $\mathrm{Cr}_{2} \mathrm{O}_{8}$ remained unchanged in contact with chromium metal base.

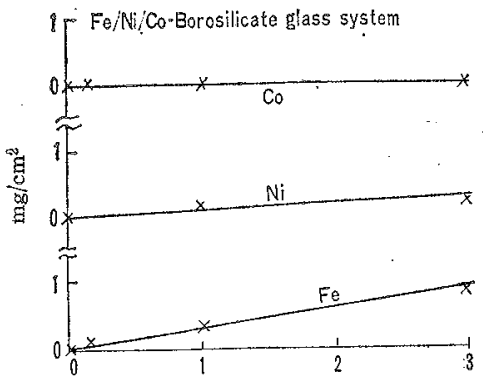

$\mathrm{h}$
(a)

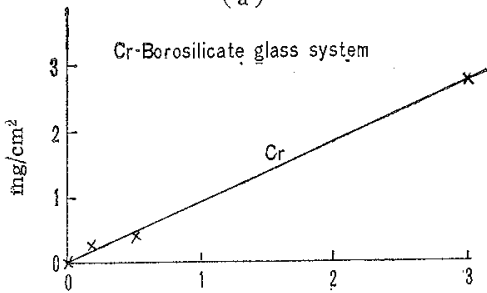

h

(b)

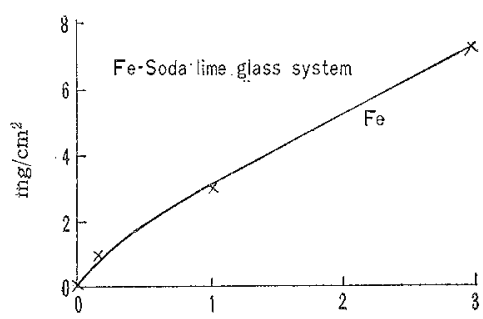

h

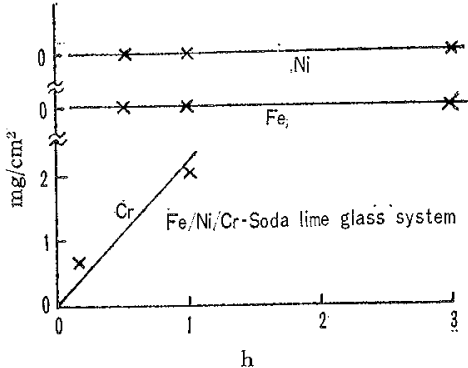

(d)

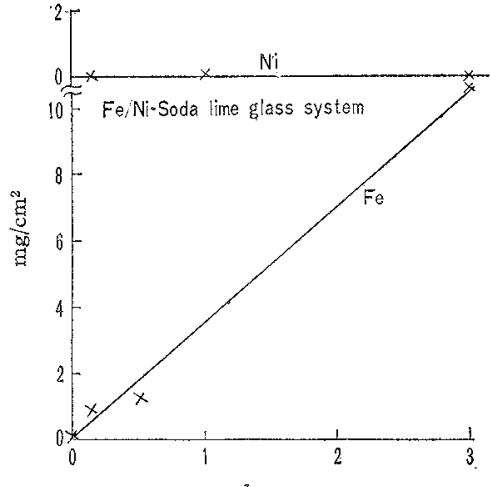

$\mathrm{h}$

(e)
して得た X 線回折図である。指数を記入したピークは $\mathrm{Cr}_{2} \mathrm{O}_{3}$ (六方晶) 飞対店して招り，ガラス中の未熔解酸 化物は融着前後とも $\mathrm{Cr}_{2} \mathrm{O}_{3}$ のの形起保持している。した がって，銅のように原子価の異なった 2 種の酸化物と金 属銅の間の平衡によって金属基板を侵蝕する反忘注考光 難い、クロム注酸素との結合力が強いからこのような 場合に $\mathrm{Cr}_{2} \mathrm{O}_{3}$ 以外に低位の酸化物が生成される可能性 はまずないと考えてよからう。

他の系列については, 先に示した図-4〜7 の状態加ら 容易に推定できるからら省略する。

\section{5. 酸化されていない金属とガラスの反応}

上記の実験で，金属基板を酸化させてガラスと融着さ せる代わりに，金属酸化物をガラス中に添加しこれと酸 化されていない金属を融着させて，金属酸化物が接着に およぼす効果を調べを。ところで，実際の封止作業では

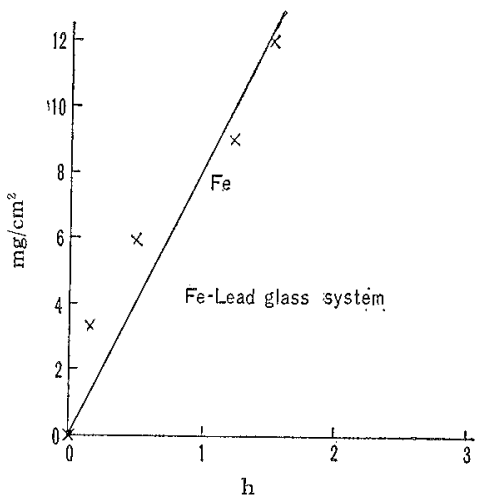

(f)

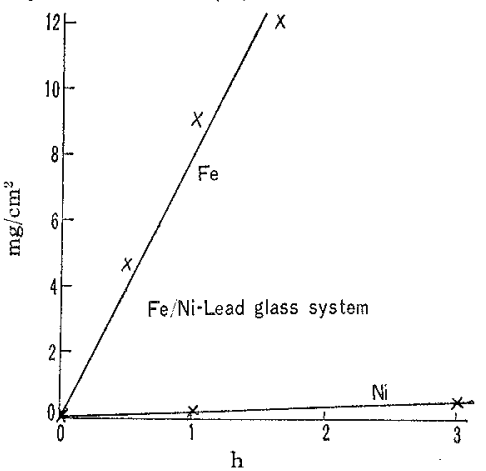

h

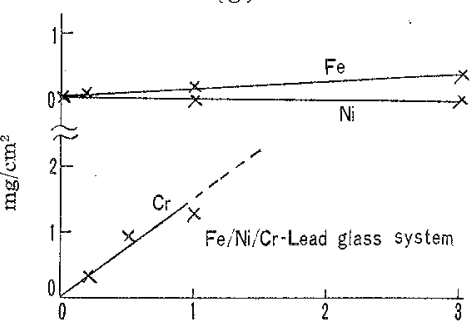

$\mathrm{h}$

(h)

Fig. 11. Dissolution of base metals into glasses. Specimens were heated at $900^{\circ} \mathrm{C}$ in vacuum $\left(\sim 10^{-5}\right.$ $\mathrm{mmHg}$ ). On glasses separated from metals, the amount of metals dissolved in glasses was determined by fluorescent X-ray analysis. 
金属を酸化させて接着力の改善をはかっているが，酸化 の效果を知るため江，酸化さ礼ていない金属と金属酸化 物堂熔解していはいがラスとの反応をもら少し調べてみ る必要がある。它こで，真空熱処理を施した清浄な金属 と金属酸化物を添加していないガラスを真空中で加熱融 着さ壮て，金属がガラス中にどの程度熔解されるか調べ てみた。融着は $10^{-5} \mathrm{mmHg}$ の真空中で, $900^{\circ} \mathrm{C}$ で所定 の時閒だけ加熱することによって行宗った。金属柱，25 $\times 25 \times 2 \mathrm{~mm}$ の浅い箱の㔙に成形し，この中にガラス粒 をみえして用いるようにした。所定の加熱を施した後， 箱を拡げで機械的にガラスをはがして集めた。この操作 で全ガラス量の約 $99 \%$ が国收された。集めたガラスは 瑪玟乳錸中で飛散しない上らに充分注意しながら粉砕し た。これと別に，既知量の金属孛熔解させた標準がラス 粉を用意し，これを円板状に成形して標準試料とし，こ れと同じ条件で成形した試料ガラス学通常の蛍光 X 線 分析法で定量し，ガラス中に熔出した金属の濃度を求め た。試料ガラス中の金属濃度, 金属とガラスの接触面積 枋よび試料ガラスの全重量が決定されれば，所定の加熱 時闆中の単位面積めたりの金属熔出量は容易に計算でき る. 図-11 は, このようにして求めた金属のガラス中い の螾出状態を示すものである.この場合，金属の熔出速 度社かなり扔そく，金属の濃度と絶対量声小さいため に，精密な定量的解析はできないが，つぎに述べるよう な興味ある事実が見られる。すなわち，基体金属が合金 の場合には，最む酸化されやすい金属成分が選択的に熔 出され，他の金属の熔出はかなり強く抑えられていると いうことである．ここで各金属の酸化物の生成エネルギ 一 $\left(-\Delta \mathrm{H}, \mathrm{kcal} / \mathrm{mol}, 25^{\circ} \mathrm{C}, 1 \mathrm{~atm}\right)^{14)}$ 此較してみる と, $\mathrm{Cr}_{2} \mathrm{O}_{3}$ は 288.9, $\mathrm{FeO}$ は $64.6, \mathrm{NiO}$ 注 $58.4, \mathrm{CoO}$ は $57.5, \mathrm{Cu}_{2} \mathrm{O}$ は $33, \mathrm{CuO}$ は 33 である。このよう な傾向から双て，金属はガラス中の酸素之結合して酸化 され，酸化されたものがガラス中に熔出寸ると觮秎して よさそうに思われる。

\section{4. 考察・結論}

実際の気密封止作業は，適度に酸化された金属とガラ スを融着することによって行なわれるのが普通である。 したがって金属表面酸化物は当然ガラス中に熔解され， 金属に接したガラス部分には界面から離机るにしたがっ て潮隇するよらな金属酸化物の濃度勾配㤎できる。この 酸化物蜄度注接着機構においてきわわて重要な意味を持 っている ${ }^{15}$ ). 本実験法, 界面に未熔解の状態 (ガラスに よって酸化されたもの注別として）で介在する酸化物の 効果分離し，唯ラス中に榕け込んだ酸化物がガラスと 金属の結合にどのよらに寄与するかといらこと当明らか にするために，㐫らかじめ酸化物を添加したガラスと酸 化されていない金属を融着させたものである。
また実際の封止作紫性，窒素中で行なわれる場合と空 気中でガスバーナーによって行なわれる場合がある。た とえば，半導体外囲器などに用いられる“ハーメチック シ一ル"梳前の場合が多〈 ${ }^{16\rangle, 17\rangle}$ ，真空管恃後の場合が大 部分である、したがって，特に接触角関して，後者の 場合注本実娩とかなり条件が異なるものと孝光られる。

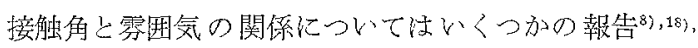
19)が女るが，一般に酸化性の雾园気のほらが接触角任小 さくなると考えられている。亦た接触角は，熔融ガラス の表面張力と金属とガラスの界面エネルギー（これは仙 者の結合力が強ければ小さな值になる) が小さいほど低 下する ${ }^{15}$ ，乙たがって，単に接触角が小さいというだけ で，雨者の結合力が強いといら証明に惊ならない。

以上のような問題加ら，単一の現象から厳密な論議は できないが，本実験で明らかにされた各現象を総合的に 解橎し, さらに他の文献を佼比することによって, 実際 の気密封此に㧍汀告接着機構をかなり明瞭に推定するこ とができる。つぎに個々の材料の瑝合について，ガラス と金属の接着機構を考えてみる。

\section{1. 鉄亡ソーダライムガラス}

この系は実用的に注半導体外囲器として使用されて就 り、ほとんど例外なしにコンプレッションシール゙20)の形 で用いられている。

本実䍄の結果をみると，実際の封止作業の上らに金属 を酸化させる代わりに，要らかじ酸化鉄をガラス中に 斿解させて金属（酸化されていない）と融着させれば， 接着強度壮著しく改善される。この場合, 鉄を酸化させ てガラスと融着させた場合 ${ }^{17)}$ と同様に，鉄の表面は侵蝕 されて凹凸ができる・招そらく

$\mathrm{Fe}_{2} \mathrm{O}_{3}$ (in glass) $+\mathrm{Fe}$ (base) $\rightarrow 3 \mathrm{FeO}$ (in glass)

$\mathrm{Fe}_{3} \mathrm{O}_{4}$ (in glass) $+\mathrm{Fe}$ (base) $\rightarrow 4 \mathrm{FeO}$ (in glass)

のような酸化還元反店によって，基板表面の鉄がガラス 中に裕出されることによるもので㠰らう，要するに，こ の系では機械的結合はかなり重要な効果を持っているす のと思われる。

つぎに，酸化鉄定螾解したガラスの性質孛考杂て子よ

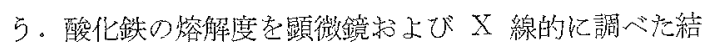
果, 添加量 $20 \%$ までは未熔解酸化鉄の相の存在は認め られなかったので, ここで注，この䈟囲に限って論ず る。熱膨脹曲線加らみると, ガラスが酸化跌を熔解する ことによって，その熱膨脹率はわずか上上昇し，屈伏点 はわずかに低下している。これらの結果から，つぎのよ らな接着機構の可能性が考克られる。すなわら, ガラス 中に熔解された酸化鉃は, ネットワーク形成酸化物とネ ットワーク修飾酸化物の二つの状態で平衡を保ってい る る11 上考光られる。後者がシリカ四面体からなるネット ワークの㖪素架橋を切断すれば，ネットワークの結合力 は減少し, その結果熱膨脹率注加し, 屈伏点法下低下 
当と考光ら礼 板表面の鉄と結 当・委た切断さ 和た結合手が基 合すると考光れ ば, ガラス酸 化鉄を熔解させ ることにより接 触角汃減少する 現象も説明でき る.これらの機 構を模型的に 図示すれば，図 -12のと标りで

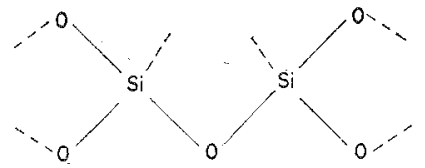

(a)

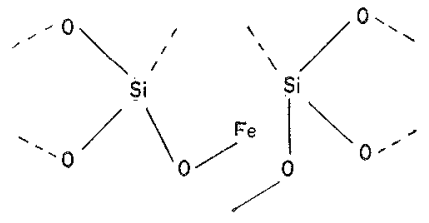

(b)

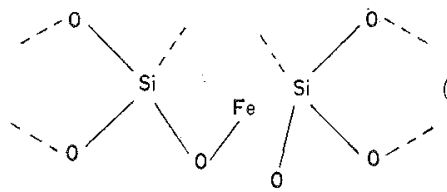

(c)

西る。

B. W. King ら゙によれば， ガラス自身の抗 張力は, 5.625 $\mathrm{kg} / \mathrm{mm}^{2}$ (原著で 程度で㐫り，こ
$\mathrm{Fe}_{\mathrm{Fe}} \mathrm{Fe} \quad \mathrm{Fe}_{\mathrm{e}} \mathrm{Fe} \quad \mathrm{Fe}$

\section{$\mathrm{Fe} \quad \mathrm{Fe} \quad \mathrm{Fe} \quad \mathrm{Fe}$}

(a) initial state. (b) loosening of the network structure by dissolution of the oxide. (c) completion of bonding.

Fig. 12. Mechanism of chemical bonding. は $\left.8000 \mathrm{lb} / \mathrm{in}^{2}\right)$

れと金属を機械的にかみ合わせた場合の引張り強度 $3.516 \mathrm{~kg} / \mathrm{mm}^{2}$ (原著で注 $5000 \mathrm{lb} / \mathrm{in}^{2}$ ) 以上にはならな い。このように考えると，界面がはげるより先にガラス が砕汀るものは，機械的結合だけによるものではないこ とになる。この場合には，抒そらく結合力の強、化学結 合が重畳されていると解瀵すべきであるう。

非酸化状態で融着させ，ガラスと鉄の界面の部分でき れいにはがれるものは,ファンデアワールス結合によっ ているといら解䣋导できる。しかし，真空中に㧍ける鉄 のガラス中への熔出状況から，鉄法ガラス中の酸素によ って酸化され，酸化されたものが熔出されると考光れ ば，この場合でも化学結合がある程度関倸するものと思 われる。

\section{2. 鉄・ニッケル・コバルト合金と磞珪酸ガラス}

この合金注嗍珪酸ガラスと熱膨脹率がよく一致し，実 用的に注ほとしどこのガラスと組み合わせて用いられ る。

この系の実用封止体の場合の機械的結合状態につい て，鉄とソーダライムガラスの場合と比較した顕微鏡観 察結果㳉すで赤告 ${ }^{22}$ したと扔りで岁る。この結果によ ると，実用封止体でほ，この合金の場合の機械的結合効 果注鉄の場合より山るか法いと考えられる結諭が得ら れたが，本実験でも合金の表面の侵蝕状態汃ら同じ傾向 が認められる (Fig. 5)。

つぎに，酸化物を熔解したガラスの熱膨脹特性の変化 について考えてみると，熔解量の増加に従って熱膨镺率

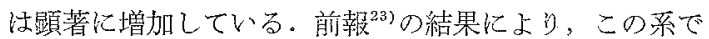
は，30\% 位まで酸化物はガラス中に嵱解しらる(長時 間加熱すると失透するが）方ら，この範囲に限って考え ると, 同系列のガラスに関して, 熱膨脹率の增加はネッ トワークの結合力の低下を意味していると解䣋される。

ところで，ネットワークの結合力が低下す玌ば，杂れ に応じて屈伏点も低下する梳ずであるが，この場合の屈 伏点の低下法熱膨脤率の堌加の割に洨岕まり顕著ではな い、この点に関しては，はっきりした根执があるわけで はないが，つぎのようなことも考えられる。すなわち， 一般に嗍理酸ガラス注分相しやすい傾向孛有し, 分相し たガラスでは異常膨脹の温度域が広いことが特長とされ ている ${ }^{24)}$ 。これは，分相によって生成された“軟い相”が 屈曲点に，“硬い相”功屈伏点に反映する結果であると 考えられている ${ }^{24)}$ 。ここで，この系の場合 (図-2(b)) を見ると, 酸化物添加量 $20 \%$ で怯，屈伏点の低下より も屈曲点の低下のほうが大きく, 異常膨脹の温度域が広 がっているように感しららる。化学結合に法“軟い相” の㟢与が大きいはずであるから，屈伏点の低下が顕著で なくても，上記のような化学結合の效果は実際には著し いといら可能性も充分考えられる。

いずれにせよ，この系では酸化物がネットワーク自身 の結合力を弱める効果を持っていることは確かである う、またこの合金の酸化物法大部分鉄で岀り，これはガ ラス中でネットワーク形成酸化物就よびネットワーク修 飾酸化物になっている ${ }^{21}$ と考えられる。化学結合を考光 る場合には，後者のほらが図-12 亿示したよらな機棈办 ら考えてより有效であるらと思われる。しかしながら， ネットワーク形成酸化物になったとしても，その結合力 が弱ければ，その部分が切机て金属基板側に向く可能性 がふらることになるから，必ずしもガラス中に㧍汀る酸 化物の結合形態にこだわる必要はないかも知れない，接 触角注酸化物の愹解に上って顕著に隇少している, 要す るに，これらの現象恃化学結合の機構によくあて性まる よう纪思方机る。

つぎに，これらの現象と，合金を酸化させてガラスと 融着させる実用的封止作業との関係を考えてみる。実際 の封止作業で忟，表面酸化物生成量に注許容されらる上 限と下限が要り ${ }^{25)}$, 酸化物怯融着に際してガラス中に熔 かし込多すぎても㐫るいは不足しても不都合である。こ の状態は封止部の色調で管理されており，薄㸚ず多色が よいとされている。合金の㗂化物は黒色であるが、ここれ がガラス中に熔解されるに従って色が薄くなり，薄初ず み色堂経過して最終的には金属光沢になる。こ礼らは， 酸化物がガラス中に愹解されることによって，合金と結 合しらる有效な結合手を増加させ，この密度军最適条件 に保持しなけ就な゙なないということを意味しているも のと思市尚。 
しかし一方，この合金では，表面酸化物の密着が雭け 水ば最終的にでき上がった封止体のガラスと合金の接着 は弱いといら事実 ${ }^{16)}$ 㪀られている。この点に関して 注，合金の表面酸化物（未熔解の）䘮介して合金上ガラ スが按着されると考えれば理解しやすい。結局この現象 上，さきに述べた化学結合の機構で多く現象をよく説明 できる点と，表面酸化物が合金の結晶粒界の部分で内部 红食い込んだような形で生成される点 ${ }^{26)}$ な゙を考完合わ せると，実用封止体の場合には，合金の粒界部分におけ る末熔解酸化物堂介した結合と他の部分における化学結 合が共存しているように思われる。

\section{3. クロムとガラス}

クロムとガラスが非常に接着しやすいこと注事実であ る、実用的に使用される場合には，ク口ム含有する合 金中のク口ムを湿潤水素中で選択酸化させて $\mathrm{Cr}_{2} \mathrm{O}_{3}$ の 被膜を作るか，あるい核適当な金属汸ロムメッキを施 し，同倳に酸化させてから封止する。

酸化ク口ムの挙動法他の系の場合とかなり異なってお 引，ガラス中の酸化ク口ム熔解量が増加すると接触角は 大きくなるが，接着強度はこれと無関係にほとんじ影響 を受けていない。熱膨脹率注, 酸化ク口ムの熔解によ。 て,ソーダライム系ガラスと鉛ガラスの場合には滅少し て扔り，硼珪酸ガラスの場合には増加している。したが って, 接触角, 接着強度および熱膨脤率などから, さき

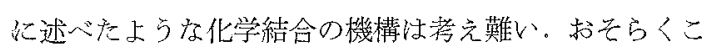
の場合には，ク口ムが酸素と非常に結合しやすく，真空 中でも容易にガラス中の酸素と結合してガラス中に熔出 されまたガラス中の酸化ク口ム含有量と無関倸に接着 強度が強い点などを考光合わせると，他の金属の場合の ようにネットワークの結合力を酸化物の熔解によって低 下させなくても，基板表面のクロムとネットワークの間 に化学結合が生ずるものと思われる。

つぎに，実用封止体の場合について考光てみよう。タ 口ムを含有する合金または夕口ムをメッキした金属注， 一般に湿潤水素中で加熱して $\mathrm{Cr}_{2} \mathrm{O}_{3}$ 孛生成させてから ガラスと融着させる。封止部の色調法, 一般に緑色 ${ }^{27)}$ (原著ではオリーブグリーンと表現してある)がよいと されているが，金属孛酸化させないよらに注意して封止

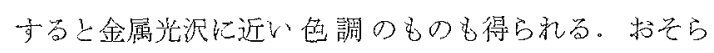
く, 封止部の色調が緑色を呈するもの梳, 未熔解酸化 物を介した接着であり，気密封止としてはこのような機 構による涪うが信頼性が高いものと思われる。乙かしな がら，しいて表面酸化物を生成させなくても，ク口ム注 酸素と結合しやすいために，ガラス中の酸素によって酸 化された薄い酸化物の層が常に生成されているとも考完 られる・したがって，金属省らかじめ酸化させなくて も，金属一酸化物一ガラスの結合が生じ，酸化の程度や 融着時間弾に酸化物層の厚さを変えているだけかる知
れない、㧍そらく、酸化物層が最も薄くなるよらな条件 でも，図-12 に示したよらな単純な機構注存在しないも のと思われる。

この系では，金属表面に四凸強いて生成させなくて もかなり強固な接着が得られる点から，機械的結合力を それほど重視する必要はないように思われる。

\section{4. 銅とガラス}

害用的にはデュメット線の形で用いられる場合が多

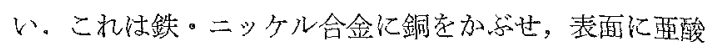
化銅を生成させ，その表面を硯砂で保護したものであ る。碽砂㹥銅の過酸化を防止するために用いられてい る。

本害験の結果をみると，ガラス中に酸化銅を熔解させ ると，接触角の最小点が現われ，接着強度も増加してい る。しかしながら，酸化物の熔解によるガラスの熱膨脹 率と屈伏点の変化加らガラスのネットワークの強度が低 下していると推定するに江無理がある。すなるち，嶰理 酸ガラスの場合には，熱膨脹率は増加しているが屈伏点 もかなり大きく上帠している。ソーダライムガラスの場 合には，屈伏点訬し低下しているが熱膨脹率もかなり 大きく低下している。酸化物を $20 \%$ 熔解した鉛ガラス 注屈伏点が低下し，熱膨脹率が嬶加しているが，市まり 顕著な変化ではない。これらの現象圭総合して考える と，図-12 に示したような化学結合の機構は考光難い が，酸化物の熔解が接着強度を増加させているのは確か な事実である。お去らく

$\mathrm{CuO}$ (in glass) $+\mathrm{Cu}$ (surface of metal) $\rightarrow \mathrm{Cu}_{2} \mathrm{O}$ で示さ机る酸化還元反応によって銅の表面飞一価の銅人 オン層もしくは业酸化銅の単分子層吕作られるというよ らな機構で接着が促進されるのではないかと想像され る。また表面に亜酸化銅が析出し：これがガラスと銅を 機械的に結合させるといらことも考穴られるが，亚酸化 銅と銅の接着を考劣ると，本質的にいま述べを機構と同 しことになる。また界面の凹凹による機倳的結合力る関 係しているものと想像されるが，図一7から推定して亦 まり效果的とは思初れい。

ここで，実際に用いられている実用封止体の晹合につ いて考えてみよら、封止部の色調は一般にルビ一色が上 い28) とされており，この色暁き込文（表面酸化物亡力゙ ラスをなじませるをめの加熱工程）学強くすると次第に 薄くなり金属銅の光沢が現われてくる。酸化物の厭さが 薄すぎるとガラスへの熔解が少なく，焼き远みによって 金属とガラスが直接接するようになると侌密性注良好だ が機械的強さ法著しく低下寸る ${ }^{29}$ 。末熔解の酸化物層が 厚ければ，この層加らスローリークするる。図一13は， 実用封止体の断面を電子顕微鏡で観察した結果の一例 で，酸化物層（来熔解の）が厚すぎる場合と，焼き远子 が強すぎて金属銅光沢に近い色調を呈した場合の組織党 
示すものであ る. 後の場合で も,この例では 若干の未熔解酸 化物が残留し ているようであ る.

このようなこ とから，実用的 には酸化物層を 介した接着が好 ましく,このた めに酸化の条件 が非常に重要で あると解䣋され る。また本実験 の結果加ら, 酸 化物を介在させ なくても，楼を らく化学結合, 銅表面の電気化 学的侵蝕による 機械的結合ある 、は亜酸化銅の 析出(銅表面に) による結合など によると考えら れるが，酸化物

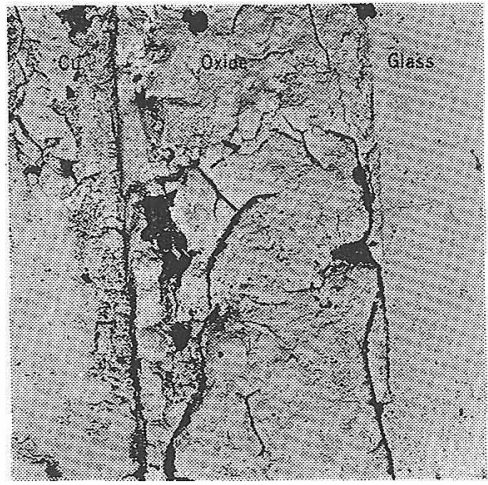

(a)

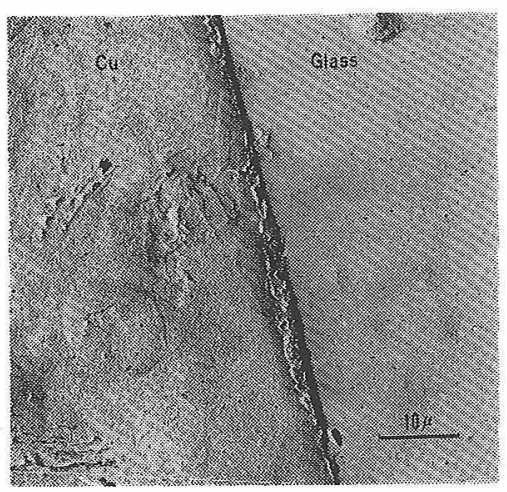

(b)

(a) Heavy oxide seal of dark ruby color. (b) Light oxide seal of bright metallic color.

Fig. 13 Electron micrographs of interfaces of lead glass to copper metal seals.
を充分ガラス中に熔かし込ルで強固な接着を得ることも 可能であると推定される.

つぎに，上に述べたような気密封止体の場合といわゆ る珪郎の場合の接着機構の差異について考えてみよう。

実際の跣郎作業は空気中で行なわれる場合が多い。し たがって鉄板は常にある程度酸化され，この酸化物がガ ラス中に熔け込んだ後の鉄の表面は多かれ少なかれ粗く なるはずである．また，鉄板の表面に二ッケルフラッシ ュが施こされた場合およびフリット中に酸化コバルトが 添加されている場合には，界面に極部電池が形成され， これ結果的に鉄板の表面に凹凸を作ると考えられる。 また，前処理としてしばしば酸洗いが行なわれるがこ れも機械的結合に寄与するはずである。

フリット中にはよく酸化コバルトが添加されるが，酸 化コバルトは $0.5 \%$ 位加らか子りの効果を示し ${ }^{5}$, 適当 な熱処理で界面に針状結晶赽析出し，さらに添加量が増

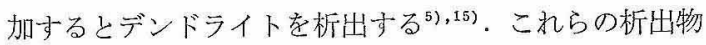
注六方最密充填型の金属コバルトである ${ }^{5}$. 鉄板表面に ニッケルフラッシニを施した場合にも，同様な反応の可 能性が期待できるように思われる。、ずれにせよこの種
の反応もまた機械的結合力を強めるものと思われる．

フリット中の酸化コバルトは, 自分自身が還元されて 鉄板の表面に析出すると同時に，鉄板の表面を酸化させ てガラス相中の鉄イオンの濃度を高める15)。一方，鉄板 の表面に析出したコバルトは，表面に鉄コバルト合金を 作る ${ }^{5), 15)}$ 。このため，鉄板表面の鉄の濃度を減少させ， ガラス相中の鉄の濃度を増加させるから, 界面の熱力学 的平衡状態は保持され易くなる.J.A. Pask ら ${ }^{15}$ 恬この 状態を重視して㐨り，鉄に接するガラス相中の $\mathrm{FeO}$ が 平衡状態にあるとき強固な化学結合が生ずると考えてい る.このような，鉄とガラスの直接的な化学結合に関す 当概念は，彼らの一連の報告 ${ }^{-6)-13)}$ に詳細に述べられて いる。

以上のような点から，いわ劥る珐郎の場合の接着機構 は, 酸化の不均一, 電気化学的侵蝕作用およびコバル卜 の析出などに起因する機械的結合と，鉄とガラスの化学 結合によっているものと解される。

これとさきに述べた気密封止の場合を比較しこれれら の差異を要約するとつぎのようになる。

鉄封止の場合と珄郎の場合の接着機構は本質的には同 ビであるう．ただし，コバルト着色ガラスを用いる場合 を除けば，前者にはコバルトの析出や合金の生成による 効果は期待できない。

鉄・ニッケル・コバルト合金の場合も，ほとんど㺼郎 の場合と同じであるように思われる、ただし，著者が封 止体の界面を钼察した結果では, 珐郎の場合について J.H. Healy ${ }^{5}$ らが示したような組織はみられなかった。 合金中には約 $17 \%$ のコバルトが含まれているから，金 属コバルトの析出は恢琪の場合より困難（コバルトが熔 出する方向に平衡が移動する）と思われる。しかしなが らこの封止では，着色剂としてガラス中にコバルトを添 加することもあり，また合金の表面酸化物中には少量の

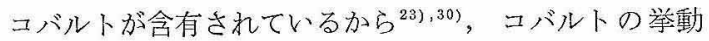
を無視するわけにはいかないだろう。

銅，クロムおよびクロムを含有する合金とガラスの封 止の場合の接着機構は，理郎の場合のそれとかなり異な っている.これらの封止体の標準的なものは、ずれも 酸化膜を介して結合していると思われるが，泆郎の場合 にはこのような機構が主流であるとは考光難い，すなわ ら，焼きが不足し界面に比較的厚い酸化物が介在寸ると 接着法弱いが，これを高温で焼いて介在する酸化物の厚 さを減少ささるだけで珐唧の接着強度が急に改善される といら事実 ${ }^{2}$ をここのよな機構から説明するには無理 があるように思われる。

\section{5. 総 括}

ガラス対金属封止における接着機構，特に金属表面酸 化物の效果を明らかにするために，上記のよらな模型的 


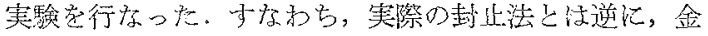

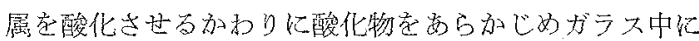
熔解させ，これ在試料として用いた。

このような手法により，分ラス中に熔出した酸化物が

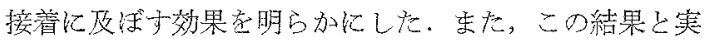
際の封止技術の諸問題を対比して，個々の材料の場合の 接着機構について論じた。

結論として，多くの機構が接着に関係しており，個ぬ の材料汇よって各機構の寄与の度合は異なっているのが わかった。さらに秓唧技術の立場加ら提唱されている代 表的接着機構と気密封止の愓合の接着機構の関連性をあ る程度明確にすることができた。

\section{参考文献}

1) R.B. Adam and J.A. Pask. J. Am. Ceram. Soc. 44 [9] 428-29 (1961).

2) B.W. King, H.P. Tripp and W.H. Duckworth, ibid. 42 [11] 504-25 (1959).

3）池田 豊, 䇺協, 72 [2] 29-37 (1964).

4) J.H. Partridge, Glass to Metal Seals, Soc. Glass Tech., England p. 213 (1949).

5) J.H. Healy and A.I. Andrews, J. Am. Ceram, Soc, 34 [8] 207-14 (1951).

6) F.D. Gaidos and J.A. Pask, Advances in Glass Technology (VI International Congress on Glass) p. 548 (1962).

7) K. Kautz, J. Am. Ceram. Soc. 20 [4] 115-20(1937).

8) V.F. Zackay, D.W. Mitchell, S.P. Mitoff and J.A. Pask, J. Am. Ceram. Soc. 36 [3] 84-89 (1953).

9) R.M. Fultath, S.P. Mitoff and J.A. Pask, ibid. 40 [8] 269-74 (1957).
10) M.L. Volpe, R.M. Fulrath and J.A. Pask, ibid. 42 [2] 102-6 (1957).

11) R.W. Cline, R.M. Fulrath and J.A. Pask, ibid. 44 [9] 423-28 (1961).

12) L.G. Hagan and S.F. Ravitz, ibid. 4A, [9] 428-29 (1961).

13) J.A. Pask and R.M. Fulrath, ibid. 45 [12] 592-96 (1962).

15）日本化学会編, 化学便覽, 丸盖, 724-37 頁 (1958).

15) M.P. Borom and J.A. Pask, J. Am. Ceram. Soc., $49[1] 1-6$ (1966).

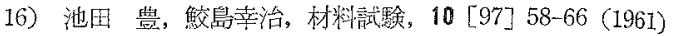

17）池田 豊, 鮫島幸治, 大井川嘉造，材料就験，11 [107] 53-61 (1962).

18) W. Weiss, Glastech. Ber. 29 [10] 386-92 (1956).

19) H.J. Oel, Ber. Deut. Ker. Gesell, 38 [6] 258-67 (1961).

20）鲛島幸治，西山睢男，筧協，73 [7] 116-21 (1965).

21）成瀬 省, ガラス王学, 粪立㑁版, 207 頁 (1958).

22) Y. Ikeda and Y. Sameshima, Proceedings of the Sixth Japan Congress on Testing Materials, 124-7 (1963).

23) Y. Ikeda and Y. Sameshima, ibid. 127-32 (1964).

24）成瀬 省, ガラス工学, 共立出版, 362 貢 (1958).

25) W.H. Kohl, Materials and Techniques for Electron Tubes, Reinhold Pub. Corp., p. 455 (1960).

26）小野員正，忘用物理，25 [12] 28-36 (1956).

27) W.H. Kohl, Materials Technology for Electron Tubes, Reinhold Pub. Corp., p. 75 (1951).

28）深川修吉, 真空管材料, オーム社, 255 頁 (1956).

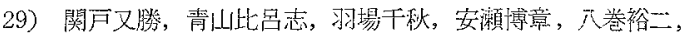
東芝レビュ一, 21 [1] 59-64 (1966).

30) R.P. Abendroth, Materials Research \& Standards, 5 [9] 459-66 (1965).

(3/7/1966 受付)

\title{
マグネシアの焼結に対する結晶形態 および酸化鉄，シリカ添加の影響
}

\author{
浜野健也。吉野一道・富警広光 \\ （東京工業大学 工業材料研究所）
}

\section{Effects of Crystal Habits of Magnesium Hydroxide, and Additions of Mron Oxide and Sillica on the Sintering of Magnesia.}

\author{
By
}

Kenya HAMANO, Kazumichi YOSHINO and Hiromitsu. TOGASHI

(Tokyo Institute of Technology, Tokyo)

As a part of the studies on the sintering behavior of the magnesia prepared by decomposition of magnesium hydroxide, effects of the crystal habits of the hydroxide, and of the additions of iron oxide and silica on the sintering process of magnesia were examined by means of measurements of dilatation and isothermal shrinkage of the specimens.

The crystal habits of the hydroxide, i.e. fibrous and massive, have no effect on the sintering process of magnesia. The addition of iron oxide promotes the sintering of magnesia, while the addition of silica rather retards the sintering, except the case when 